\title{
The Peridiniales of Plymouth Sound from the Region beyond the Breakwater.
}

\author{
By \\ Marie V. Lebour, M.Sc., \\ Assistant Lecturer in Zoology, Leeds University. \\ Temporary Naturalist at the Plymouth Laboratory.
}

With Figures 1-14 in the text.

THe following list includes all the Peridiniales identified in the plankton throughout the year from September, 1915, to September, 1916, from the water samples, details of which will be found in another paper in the same journal (p. 133). Also from the plankton in the tow nets in the same year and a portion of the summer 1915. As is shown in the abovementioned paper, the summer is the time for nearly all the Peridiniales, June being the maximum month. After October very few are seen in the water samples, although in the tow nettings the larger and stronger forms, such as Ceratium and Peridinium, are still present.

The new and least-known forms belong to the Gymnodiniacea, which have no cellulose sheath. Perfectly transparent and extremely thin cases, however, are often seen which may be close fitting or many times larger than the gymnodinian. Pouchetia and various species of Cochlodinium are instances of this (see Plate II, Fig. 14). The Gymnodiniacece are perhaps the most interesting of the Peridiniales, as many of them obtain nourishment holozoically and often the food can be determined. Throughout June the flagellate Phoocystis pouchetii was excessively abundant, and this furnished food for many gymnodinians (e.g. Gymnodinium rhomboides and G. triangularis, see Plate I, Figs. 6 and 7).

Division stages in this group are often seen which in the genera Gymnodinium and Spirodinium take place usually, if not always, in the free state and not in capsules as in Pouchetia and others (Pouchet, 1885 ; Dogiel, 1906).

Although no special investigation has been made closer inshore, the examination of a few samples of water show that many of the species occur near the land, such as Gymnodinium and Spirodinium species and Dinophysis, besides several species of Peridinium. 
In the following list 60 species are recorded. Of these 5 of Gymnodinium, 2 of Spirodinium, and one of Cochlodinium are new. Twenty-one species are, I believe, new records for British seas and 28 are new records for the Plymouth area. In addition to those recorded and described there are many which I have not been able to identify. Some of these are young forms, others collapsed before they could be properly observed, and others were distorted. Among these there are probably many new species belonging to the Gymnodiniacece.

The classification adopted is that of Paulsen (1908) in "Nordisches Plankton." Those marked * are new to Plymouth, those marked N.R. are new records for British seas.

\section{PROROCENTRACEA.}

Genus Exuviella Cienk.

(1) * Exuviella compressa (Bailey) Ostenfeld. Occasionally in water samples in the summer.

Genus Prorocentrum Ehrenberg.

(2) Prorocentrum micans Ehrenberg. From May to October in the water samples, rarely in tow nettings. Commonest in the late summer. Its maximum early in September.

\section{PERIDINIACEE.}

Genus Dinophysis Ehrenberg.

(3) Dinophysis acuta Ehrenberg. Fairly frequent in very fine tow nettings, not so common in the water samples. May to October.

(4) D. acuminata Cl. and L. Common in water samples, usually gets through the very fine net. There is a small form of this species which occurs more rarely than the type in the spring and early summer.

(5) D. ovum Schütt. Occasionally in water samples.

(6) D. rotundatum $\mathrm{Cl}$. and L. Common in water samples.

(7) D. homunculus Stein v. tripos Gourr. Occurred once only in tow nettings, August, 1916.

\section{Genus Glenodinium (Ehrenberg) Stein.}

(8) * Glenodinium bipes Pauls. Common from May to September. Abundant in May and June with its maximum in early June. This species is so small that it always gets through the very fine 
net. It is exceedingly active and lives many hours in a bottle of sea-water.

Genus Protoceratium Bergh.

(9) * Protoceratium reticulatum (Cl. and L.). Occurs fairly commonly in water samples from May to September, commonest in August.

Genus Goniaulax Diesing.

(10) * Goniaulax triacantha Jörgensen. Rare, in water samples, May to September.

(11) G. polygramma Stein. Rare, in water samples, May to September.

(12) G. spinifera (Cl. and L.). This is the commonest species of Goniaulax. May to September.

(13) N.R. G. scrippsa Kofoid. Occasionally in the water samples, July to September.

(14) G. polyedra Stein. Occasionally in water samples, May to September.

Genus Amylax Meunier.

(15) N.R. Amylax lata Meunier. Occurred a few times singly. Slightly smaller than the type.

Genus Diplopsalis Bergh.

(16) Diplopsalis lenticula Bergh. Fairly common in very fine tow nettings and in water samples. May to September.

(17) N.R. D. pillula Ostf. This minute species is abundant in June in the water samples, very often with Glenodinium bipes.

Genus Peridinium Ehrenberg.

Sub-genus Protoperidinium Bergh.

(18) Peridinium orbiculare Paulsen. Occurs rarely in the water samples.

(19) * P. cerasus Paulsen. This little species is one of the commonest and easily recognised. Occurs fairly frequently but never in large quantities in the water samples.

(20)* P. roseum Paulsen. Very like the last species but larger and flatter. Occurs rarely in the water samples. 
(21) P. ovatum (Pouchet). Common in late summer but rare in May and June. Specimens with broad and conspicuously striated interspaces between the plates are as common as the typical forms and are probably older, as Mangin (1913) has already noted. More common in tow nettings than in water samples.

(22) P. pedunculatum Schütt. Very rare, in water samples only.

(23) P. pallidum Ostf. This and the following species are both common, the present species being larger is commoner in the tow nettings.

(24) P. pellucidum (Bergh). Common in water samples.

\section{Sub-genus Euperidinium Gran.}

(25) P. oceanicum Vanh. Rare in tow nettings.

(26) P. divergens Ehrl. Abundant in the tow nettings, especially in August and early September. Following Meunier (1910) I have reunited the $P$. depressum of the "Nordisches Plankton" with this species.

(27) $P$. crassipes Kofoid. Not very common in the tow nettings in August and September.

(28) $P$. conicum (Gran). This species and $P$. divergens are almost the only peridinians to be found in winter: although not abundant $P$. conicum is found throughout the year both in tow nettings and water samples. Commonest in early spring.

(29) N.R. P. Thorianum Paulsen. Rare in water samples in June. Meunier (1910) gives good figures of this species, which resemble the Plymouth form more than do Paulsen's. The present specimens have small knobs conspicuously ornamenting the skeleton which are very characteristic.

\section{Genus Pyrophacus.}

(30) N.R. Pyrophacus horologicum Stein. Occurred very rarely in tow nettings in August.

\section{Genus Oxyтохuм Stein.}

(31) N.R. Oxytoxum Milneri Murr. and Whitt. I have referred to this species, a very small Oxytoxum about half the size of the type but agreeing with it in form. Only one specimen was found in August in the water samples. 


\section{Genus Ceratium Schrank.}

(32) N.R. Ceratium platycorne V. Duday. Rare, occurred singly two or three times in the tow nettings.

(33) C. bucephalum (Cleve). Occurred sparingly in tow nettings in early summer, more frequently in the late summer months.

(34) C. tripos (O. F. Müll.). Occasionally in water samples and tow nettings. A variety which approaches the form lineata (Ehrb.) and which I have referred to this variety occurs more frequently (Fig. 1). This has a short and straight apical horn, the hind horn nearly straight and the right horn about one-third as long as the left. The usual markings are longitudinal striations from the apex to the girdle, sometimes also with reticulations.

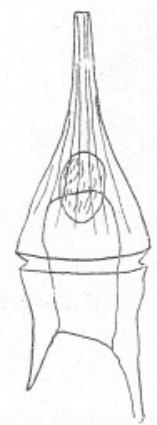

Fig. 1.-Ceratium tripos (O. F. Müll.) f. lineata (Ehrb.). $\times 466$.

Although apparently nearest to the form lineata, the apical horn is very much shorter-less than half the length from its apex to the girdle.

(35) * C. arcticum (Ehrb.). Very rare, in tow nettings, 1915.

(36) C. macroceras (Ehrb.) Cleve. Rare in tow nettings.

(37) C. furca (Ehrb.). Occasionally, in tow nettings and water samples in summer.

(38) C. fusus (Ehrb.). The commonest Ceratium here. Occurs both in tow nettings and water samples and is often the only peridinian present in the winter. Maximum in October.

\section{GYMNODINIACEÆ.}

By far the greater portion of the Peridiniales of this area belong to this group and are missed almost entirely by the tow nets, only a few of the larger forms being retained by them. 
Genus Amphidinium Cl. and L.

(39) N.R. Amphidinium crassum Lohmann. I have referred to this species, a form between $A$. crassum and A. longum of Lohmann, but which is slightly larger than either of these (Fig. 2). The shape of the body is not so pointed posteriorly as in A. longum but not so broadly rounded as in $A$. crassum, the greatest breadth being in about the centre of the body. The nucleus is posterior as in both forms, and a coloured body, greenish, is situated just in front of the nucleus and behind the transverse groove, with small refractive bodies scattered round it. This is perhaps the remains of ingested food material. A thin transparent covering can sometimes be seen detaching itself from the body. Length

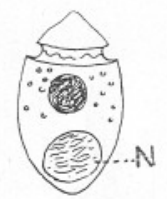

FIG. 2.-Amphidinium crassum Lohmann. $\times 466 . \quad \mathrm{N}=$ nucleus.

of body $0.030 \mathrm{~mm}$. The only record so far of this species is by Lohmann from Kiel.

\section{Genus Grmnodinium Stein.}

(40) I.R. Gymnodinium teredo Pouchet. Fairly common in July and August in the water samples in 1915, less common in 1916. This is the only gymnodinian found here in the winter months, but then only rarely. It turns up singly nearly all the year round. Many abnormalities and deformities occur and a variety of shapes is seen.

(41) N.R. G. pseudonoctiluca Pouchet (Fig. 3). To this species I refer one which agrees well with one condition of the above species, but which I never saw with the long contractile tentacle described by Pouchet (1885). It only occurred twice, the first time in medium tow nettings in July, 1915, and the second time in the water samples in June, 1916. It is rather smaller than the type (length $0.10 \mathrm{~mm}$.). The ventral surface on each side of the longitudinal groove is pulled out into a flap, the left flap slightly longer than the right. The bright yellow chromatophores radiate from the centre. The longitudinal groove is more marked than in Pouchet's figures. The nucleus is in the centre of the body. 
(42) G. viridis n. sp. (Fig. 4). Closely related to the last species is one also found only singly and which is less than half the size. In shape it is much like G. pseudonoctiluca with a cap-like anterior
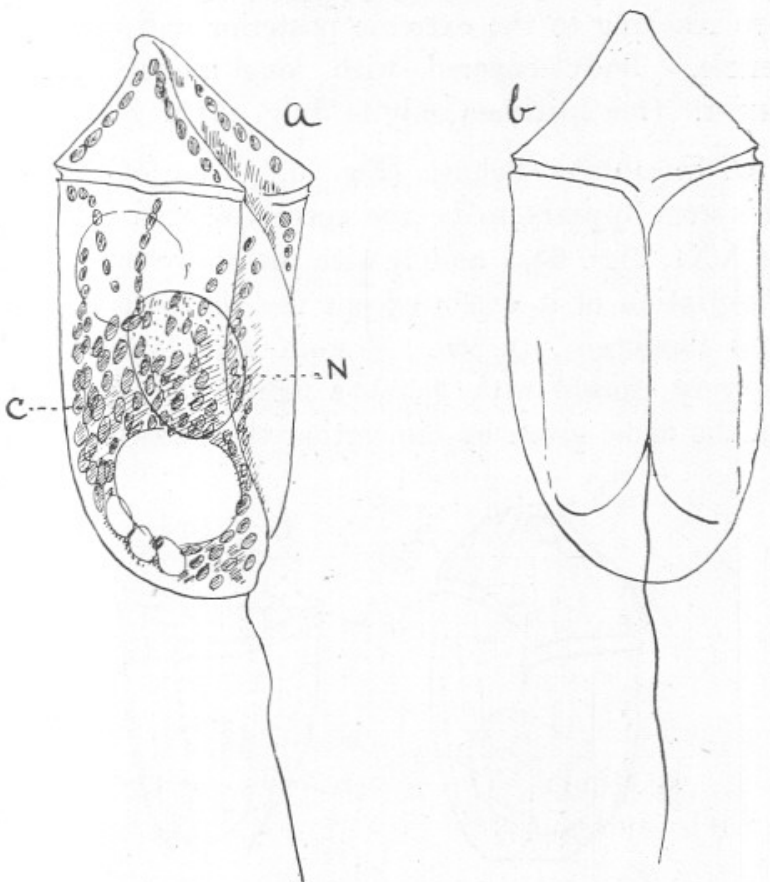

FIG. 3.-Gymnodinium pseudonoctiluca Pouchet. $\times 466$.

$a$ side view, $b$ ventral view. $\mathrm{N}=$ nucleus. $\mathrm{C}=$ chromatophores.
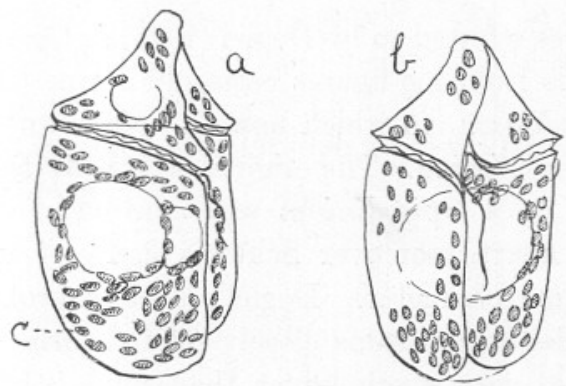

Frg. 4.-Gymnodinium viridis $\mathrm{n} . \mathrm{sp} . \quad \times 466$ $a$ side view, $b$ ventral view. $\quad \mathrm{C}=$ chromatophores.

end; the longitudinal groove, however, reaches back slightly o zer the dorsal surface posteriorly so that the hind end is divided. The chromatophores are of a greenish yellow colour, not bright yellow as in $P$. pseudonoctiluca. Length $0.06 \mathrm{~mm}$. Occurred once in June. 
(43) G. achromaticum n. sp. (Fig. 5). Related to G. viridis but without chromatophores. Perfectly colourless and transparent, transverse groove conspicuously left-handed, longitudinal groove reaching to the extreme posterior end. Apex somewhat excentric. Body covered with longitudinal striæ. Nucleus posterior. One specimen only in July, 1915.

(44) N.R. G. rhomboides Schuitt (Fig. 6). One of the commonest in this area appears to be the species figured by Schüt (1895, Plate XXI, Figs. 63, 1 and 2) with the above name. Apparently no description of it exists except the short diagnosis in "Nordisches Plankton" (p. 99). Certain aspects of my specimens agree very closely with Schütt's figures, and I have therefore taken the name given by him rather than create a new one.
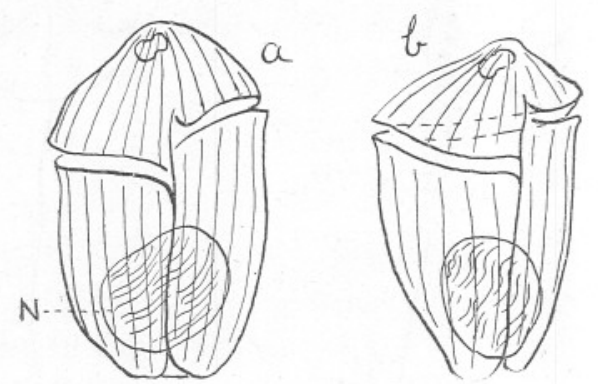

FIG. 5.-Gymnodinium achromaticum n. sp. $\times 466$. $a$ ventral view, $b$ side view. $\mathrm{N}=$ nucleus.

The species referred to by Dogiel (1906) as Gymnodinium spirale v. obtusum is from his figures certainly a true Gymnodinium and not a Spirodinium, to which now $G$. spirale and all its varieties have been transferred. The original figures by Bergh of $G$. spirale show it to be a Spirodinium with the ends of the transverse groove far apart, moreover Schütt's figure of v. obtusum shows also the same character. Dogiel's species probably belongs to $G$. rhomboides or else some closely related form. His specimens, however, are very much larger than mine. His figures of the stages in division show it in another form which is also common with us and which I have found in division and very similar to Dogiel's figures. Schütt's figure 63, 1 is also of this type, and apparently this is the form before and during division. These two forms I have therefore placed together as Gymnodinium rhomboides. The body is elongated, oval or rhomboidal, the transverse groove is only slightly displaced and left-handed, 
the longitudinal groove is inconspicuous. The whole surface is covered with longitudinal striæ, those on the anterior portion being further apart than those posteriorly. Remains of food in
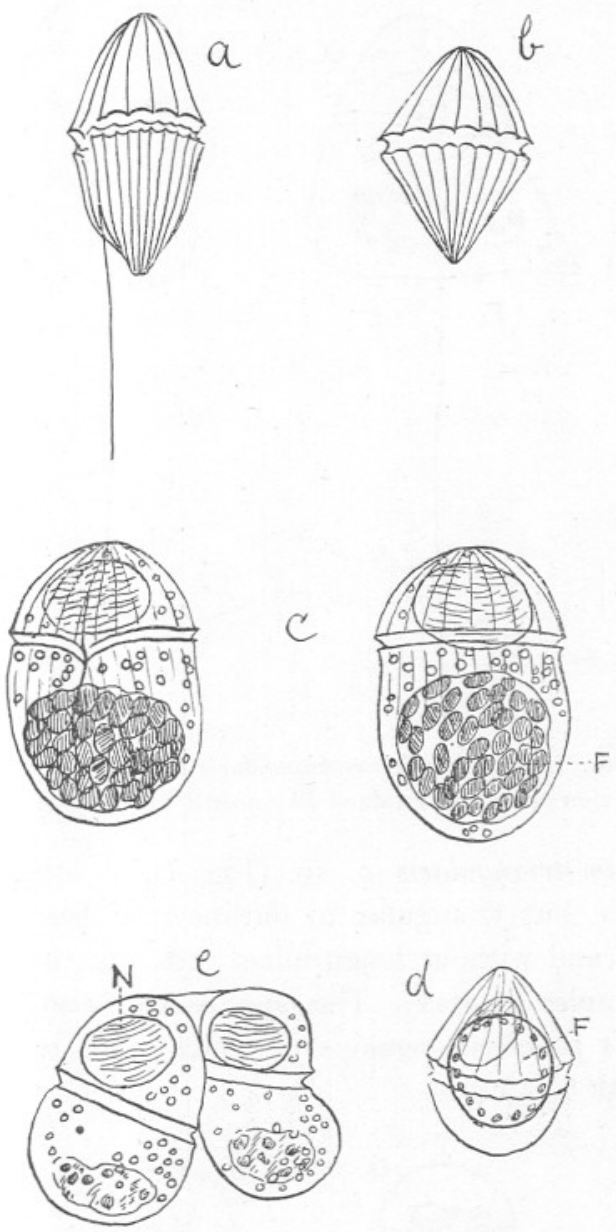

FIG, 6.-Gymnodinium rhomboides Schütt. $\times 466$

$a$ side view, $b$ dorsal view, $c$ ventral and dorsal views of older forms containing food masses of Phwocystis, $d$ young form containing a Thalassiosira, $e$ division. $\mathrm{N}=$ nucleus. $\mathrm{F}=$ food.

a ball is often seen in the hind portion of the body. Nucleus anterior. The body colourless with no chromatophores. Its food consists very often of Phaocystis pouchetii when that flagellate is abundant, at other times of diatoms ; remains of Thalassiosira and Coscinodiscus were also found inside the body. Division takes place in the free state as described and figured by Dogiel. 
This is perhaps the commonest gymnodinian and occurs close to the shore as well as beyond the Breakwater. Length of body $0.040 \mathrm{~mm}$. to $0.050 \mathrm{~mm}$
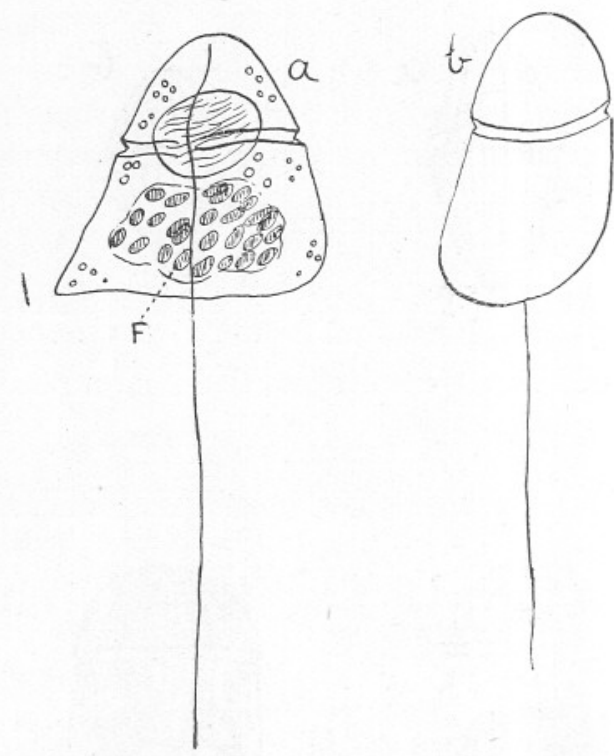

Fig. 7.-Gymnodinium triangularis n. sp. $\times 466$ i $a$ ventral view showing contained $P h$ coc $^{y} /$ stis,$b$ side view. $\mathrm{F}=$ food.

(45) Gymnodinium triangularis n. sp. (Fig. 7). Closely related to $G$. rhomboides, but triangular in outline (the base of the triangle posterior) and without longitudinal striæ on the body. Rare in water samples in May. This species had also been feeding on Phoocystis pouchetii, remains of which were recognisable inside it. Length $0.045 \mathrm{~mm}$.
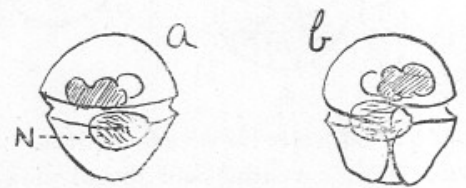

FIG. 8.-Gym odinium minor n. sp. $\times 466$. $a$ dorsal view, $b$ ventral view. $\mathrm{N}=$ nucleus.

(46) Gymnodinium minor n. sp. (Fig. 8). This little species is transparent and destitute of any sculpture. It is nearly spherical but with the posterior end slightly narrower than the anterior. Transverse groove left-handed and only slightly displaced, longitudinal groove reaching to the posterior end. Nucleus nearly 
central ; green masses, probably food material, at the anterior end. Length $0.028 \mathrm{~mm}$. Occasionally in water samples May to July.

(47) Gymnodinium filum n. sp. (Fig. 9). Body long and narrow, tapering to a thread-like point posteriorly. Anterior end conical. Transverse groove almost straight, longitudinal groove reaching about three-quarters of the way to the posterior end. Nucleus behind the centre. A dark brown mass (probably food remains) in front of and at the side of the nucleus. One specimen was found with no coloured body. Body clear and colourless with no striæ. Length 0.065 mm. Rare in water samples July, 1915. Very fragile and easily collapses.
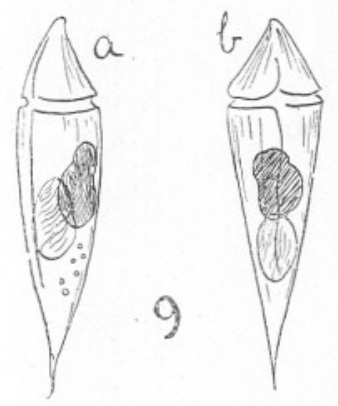

Fig. 9.-Gym rodinium filum n. sp. $\times 466$ $a$ side view, $b$ ventral view.

\section{Genus SpIrodinium Schütt.}

(48) N.R. Spirodinium fissum (Levander) Lemmermann. Occurs occasionally in August and September in water samples. Conspicuous from its yellow colour and peculiar dorso-ventral flattening. Division in the free state was noticed in September.

(49) N.R. Spirodinium spirale (Bergh) (Fig. 10). This species is exceedingly common in the water samples in many varieties. The typical form which agrees with Pouchet's description and figure (1885, p. 67, Plate IV, Fig. 30) is usually much smaller than his specimens and generally colourless, although bright yellow examples are sometimes seen, such as Pouchet himself observed occasionally. The yellow examples are always blunter at the apex than the type which is pronouncedly acuminate. My specimens, including the yellow forms, measure generally $0 \cdot 04 \mathrm{~mm}$. to $0.06 \mathrm{~mm}$., whereas Pouchet (1883-85) gives $0 \cdot 10 \mathrm{~mm}$. as the typical size. The longitudinal striations are characteristic, 
and green remains of food are sometimes to be found inside the body, also small roundish masses of fat.

The variety acutum Schütt (Plate XXI, Fig. 66) is also found, which seems to be close to the typical form and more nearly the size of Bergh's (1882) and Pouchet's specimens. Length of this variety $0 \cdot 14 \mathrm{~mm}$. One specimen which occurred in August, 1915 , was coloured a beautiful carmine, the colour xunning along
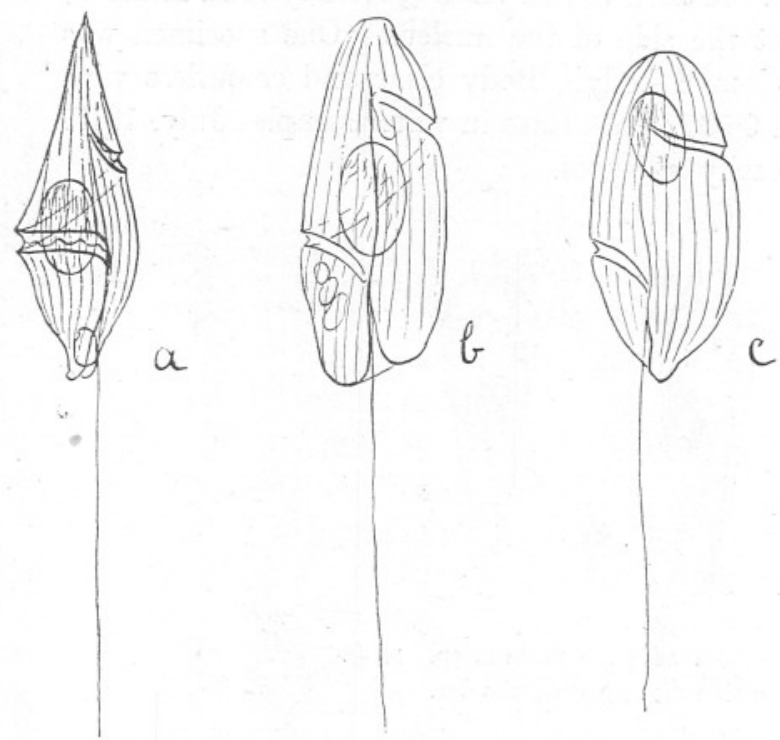

FIG. 10.-Spirodinium spirale (Bergh). $\times 466$.

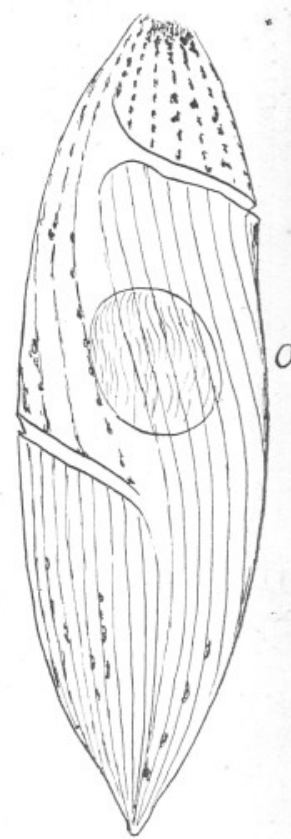

$a$ typical form, $b$ and $c$ v. obtusum Schütt, $d$ v. acuium Schütt.

the lines of the striæ in droplets. Other specimens are quite colourless.

The variety obtusum Schüt is also common but of small size. Length $0.06 \mathrm{~mm}$. usually. Characterised by its blunt apex.

(50) Spirodinium concentricum n. sp. (Fig. 11). This species is characterised by the sculpture of concentric striæ on the body, the longitudinal striæ being arranged concentrically round a certain point at the side or on the dorsal surface. Body colourless. Grooves and shape of the body very much like the variety obtusum of the preceding species. A large and a small form exist, the larger form being several times the size of the smaller. Both rare, only in the summer of 1915 . 
(51) N.R. Spirodinium crassum (Pouchet) (Fig. 12). I have referred to this species a somewhat rare form which is definitely smaller than the type, length $0.075 \mathrm{~mm}$. (type $0.12-0.2 \mathrm{~mm}$.
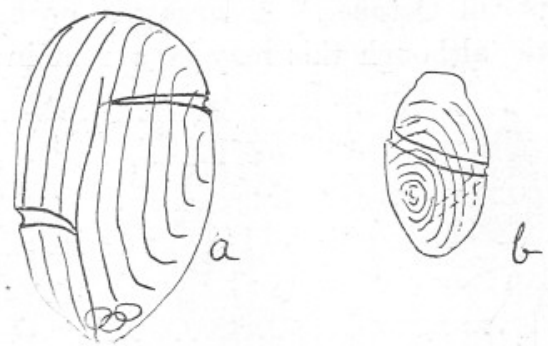

Frg. 11.-Spirodinium concentricum n. sp. $\times 466$. $a$ large form, $b$ small form.

Pouchet). In shape and contour of the furrows it corresponds and has a diffuse colouring of brownish red beginning at the apex and following the transverse furrow. Faint longitudinal striæ
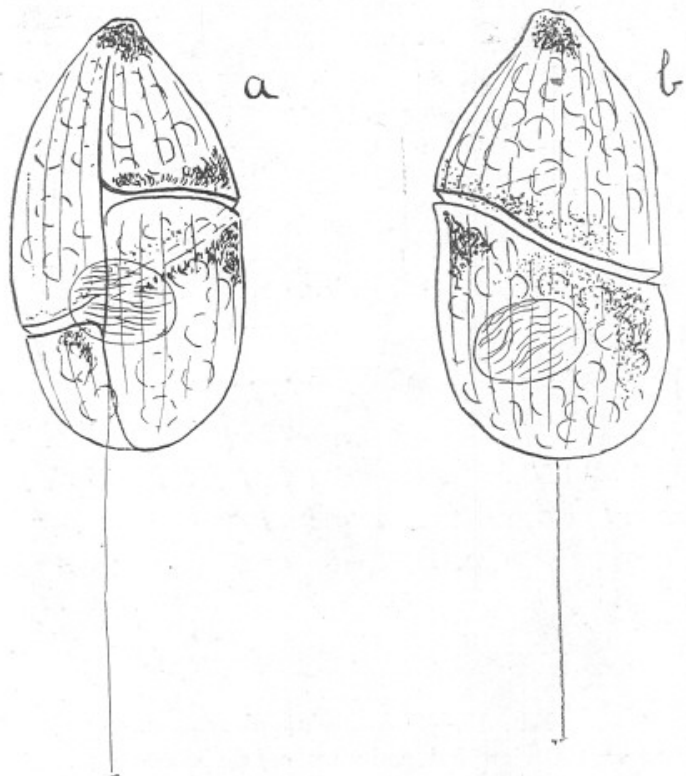

FIG. 12.-Spirodinium crassum (Pouchet). $\times 466$. $a$ ventral view, $b$ dorsal view.

are present; transverse furrow with its ends widely separated, longitudinal furrow weakly developed. Nucleus posterior. Interior of body full of large granules. Occurs occasionally in June. 
(52) Spirodinium glaucum n. sp. (Fig. 13). This is a very common species, perhaps the commonest Spirodinium in this area. It begins in May, having its maximum in May and June and persists till October. A large yellow body posteriorly is characteristic, although this may be absent in young forms and
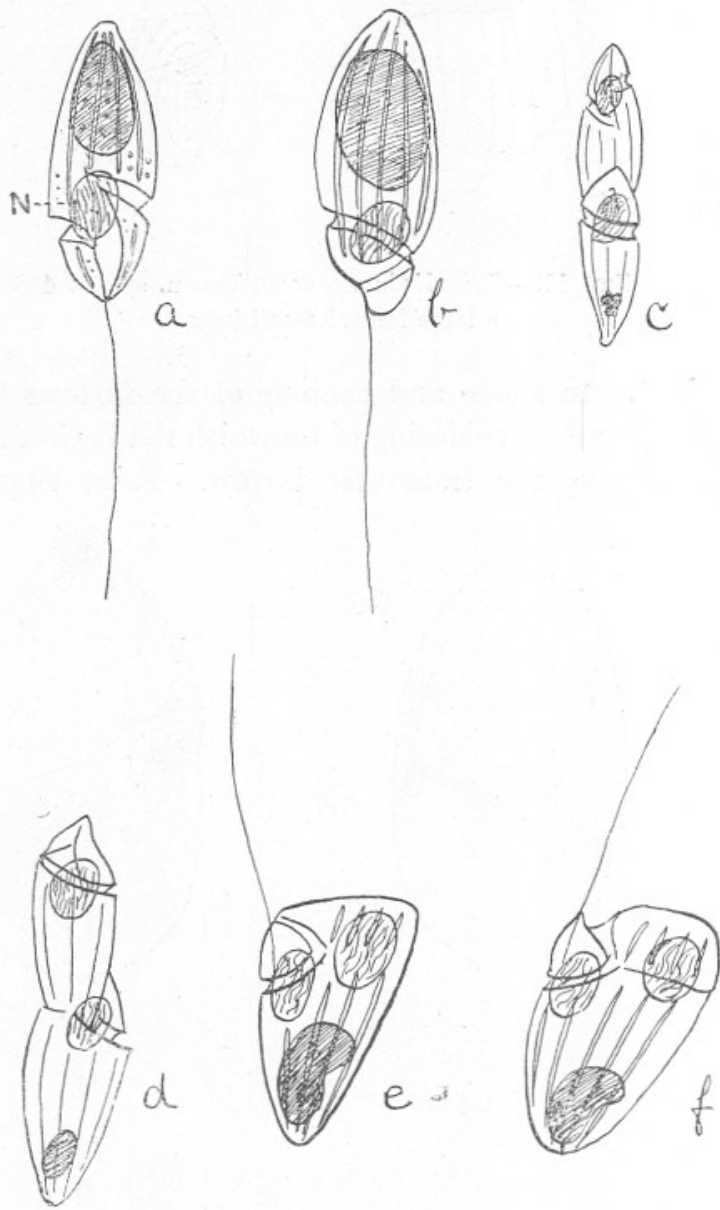

Fig. 13.-Spirodinium glaucum n. sp. $\times 466$.

$a$ ventral view, $b$ dorsal view, $c-f$ division stages. $\quad \mathrm{N}=$ nucleus.

possibly is only food remains, although it is always the same colour and in the same place. These yellow bodies are also sometimes absent in divisional stages. The body is elongated with a long anterior and short posterior portion, with a few wide apart longitudinal striæ. Transverse furrow with the ends wide apart; longitudinal furrow short and with the appearance of a 
three-cornered bite having been taken out of the posterior end. This species is rather like $G$. teredo, with the exception of the chromatophores which are numerous in the latter species. Cell colourless except for the yellow mass. Nucleus in the region of the transverse furrow. Divisional stages are often seen in the free state, one individual pushing part of its body backward so that a chain of two is formed very much like the figure given by Pouchet of the division of S. spirale (loc. cit.). Earlier stages in division show that the longitudinal flagellum persists as is described by Dogiel in his Gymnodinium spirale v. obtusum. A growth then takes place at the side of the whole body, so that the cell is very much swollen transversely; then division takes place, beginning at the posterior end as a groove and half the cell is pushed backwards so that the chain of two individuals is formed, one attached to the side of the posterior end of its fellow by its extreme anterior end. After division the individuals are small and may

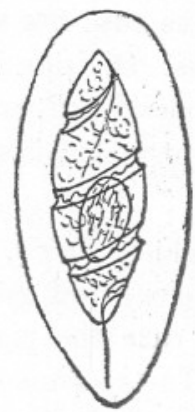

FIG. 14.-Cochlodinium pulchellum n. sp. $\times 466$.

or may not contain yellow bodies. In one case the yellow body appeared to be dividing at the same time as the cell, which perhaps shows it to be a chromatophore.

\section{Genus Cochlodinium Schütt.}

(53) N.R. Cochlodinium helix (Pouchet). Occurs occasionally in the water samples in August, sometimes free, sometimes enclosed in a spacious perfectly transparent covering.

(54) N.R. Cochlodinium pellucidum Lohmann. Rare. In the water samples in July and August.

(55) Cochlodinium pulchellum n. sp. (Fig. 14). This species was found once only in the water samples from 7 fathoms, August, 1915. It is perfectly colourless and contained in a roomy transNEW SERIES, - VOL, XI, NO, 2. MAY, 1917. 
parent case in which it rotates freely on its longitudinal axis. It is fusiform in shape, and pointed in much the same way at both ends. The transverse furrow makes three complete turns and is deeply grooved. The longitudinal furrow is inconspicuous, making over one turn round the body. Nucleus nearly central. Length of body $0.05 \mathrm{~mm}$., length of case $0.65 \mathrm{~mm}$. This species is very similar to Pouchetia fusus Schüt, but without the conspicuous lens and stigma of that form.

\section{Genus Pouchetia Schütt.}

(56) N.R. Pouchetia armata Dogiel (1906). This species, with its characteristic stinging capsules, is common in the water samples, especially in May and June. It is sometimes contained in a case, sometimes and more usually, free. Division into two within the case was seen. So far this species has only been recorded for the Mediterranean.

(57) N.R. Pouchetia parva Lohmann. This is fairly frequent in summer, especially in June. The case fits very close to the body, much closer than in P. armata. Division in the case is often seen. This species is very like Pouchet's figure (1885) of $P$. polyphemus v. nigra, the pigment, however, in his species is red and this is always black.

(58) N.R. Pouchetia fusus Schütt (1895). Occurs rarely in September. Conspicuous from its elongated body and large lens with dark red pigment. In one case the pigment mass was breaking up into small red spots. The specimens seen were always free.

\section{Genus Polykrikos Bütschli.}

(59) N.R. Polykrikos Schwarzii Bütschli. Occurs occasionally in tow nettings and water samples from May throughout the summer.

\section{PYROCYSTEÆ Apstein.}

Genus Pyrocystis Murray.

(60) Pyrocystis lunula Schütt. Occurs occasionally in tow nettings in August and September in various stages of division in the semilunar cases.

\section{Incertae sedis.}

(61) N.R. Oxyrrhis marina (Duj.). The position of Oxyrrhis is still a vexed question, and although Senn (1910) regards it as a true peridinian, the view is not universally accepted (see Klebs, 1912). In my opinion it is more of a peridinian than a true flagellate, the division 
stages of Gymnodinium and Spirodinium being closely related to those of Oxyrrhis. Oxyrrhis marina occurs sparingly in the water samples, but is to be found in great abundance in cultures in the laboratory in which it thrives with the greatest ease. In cultures of Nitzschia closterium especially it flourishes in enormous numbers, the body being full of this diatom on which it feeds.

\section{LITERATURE.}

1882. Bergh, R. S. "Der Organismus der Cilio-flagellaten." Morph. Jahrb., Bd. 7.

1906-8. Bygrave, W. " Report on the Plankton of the English Channel in 1906." M. B. A. International Fisheries Investigations, 1906-8, Cd. 4641.

1897. Cleve, P. T. "Plankton Researches in 1887." Kongl. Svensk. Vetensk. Akademiens Handlingar, Bd. 32, No. 7.

1900. _ "The Plankton of the North Sea, English Channel and the Skagerak in 1899." Ibid., Bd. 32, No. 2.

1906. Dogrel, V. "Beitrage zur Kenntnis der Peridineen." Mitt. aus der Zool., Station Neapel, 18 Bd.

1903a. Gough, L. " Plankton, English Channel, February, May, August, and November, 1903 and 1904." Bull. d. Rés. acq. pend. 1. c. périod pub. p. l. Conseil International pour l'Exploration de la Mer.

1903b. _ “ " Report on the Plankton of the English Channel in 1903." M.B.A. International Fisheries Investigations; Cd. 2670.

1905. — Cd. 3837 .

1912. GRAN, H. H. "The Plankton Production of the North European Waters in the Spring of 1912." Bull. Planktonique, 1912.

1907-14. Herdman, W. A. and Scott, A. " An Intensive Study of the Marine Plankton around the South End of the Isle of Man." Parts I-VIII. Reports for 1907-14 of the Lancashire Sea Fisheries Laboratory.

1912. Klebs, G. "Ueber Flagellaten und Algen-ähnliche Perideen." Verhandlungen der Naturhistorisch-medizinischen Vereines zu Heidelberg, N.F. Bd. 11, July, 1912.

1908. Lohmann, H. "Untersuchungen zur Feststellung des Vollständigen Gehaltes des Meeres an Plankton." Wissenschaftliche Meeresunterserchungen h.v.d. komm. z. wiss. unters. d. deutschen Meere in Kiel, 1908. 
1913. Mangin, L. "Sur la Flore planctonique de la rade de SaintVaast-la-Hougue 1908-12." Nouvelles Archives der Muséum d'Histoire naturelle, 5 Sér., 1913.

1910. Meunier, A. "Duc d'Orléans, Campagne Arctique de 1907." Microplankton des Mers de Barents et de Kara.

1908. Paulsen, O. "Nordisches Plankton," Vol. VIII. "Peridiniales."

1883. Pouchet, G. "Contribution à l'Histoire des Cilio-flagellés." J. de l'Anat. et de la Phys., 1883.

1885. — "Nouvelle contribution à l'histoire des Péridiniens marins."

1910. Senn, G. "Oxyrrhis, Nephroselmis und einige Euflagellaten." Zeitsch. Wissens. Zool., Bd. 97.

1895. Сснӥтт, F. "Die Peridinien des Plankton Expedition." I Thiel. 